benefit; but, if it was worth anything at all, it would improve with time.

The question of an Insurance Society under this system would not necessarily require to be considered; as those who could afford it would, as at present obtains, insure their lives either in one of the existing Insurance Companies, or in a special medical one, if this should be thought more desirable.

In conclusion, I would beg to offer one other suggestion entirely apart from the foregoing. It occurs to me, in connexion with the provident system, if any scheme should be forthcoming, that it would simplify matters to make provision only for cases of death and where members become permanently and not temporarily disabled. Professional men occupy a totally different position from the "working man": the income of the latter ceases during the whole period of an illness, that of the former continues under the assistance of a substitute. There are doubtless, however, cases in which a practice may be so small that every little extra expense is a consideration. Might not these exceptions be made cases for a special fund?

Apologising for having thus trespassed upon your valuable space,

June, 1873. I am, Sir, yours faithfully, a Graddate.

\section{TREATMENT OF DERMATOPHYTA.}

To the Editor of THE IAANCET.

SIR,-The obstinacy with which dermatophyta of ten resist treatment, and the tendency they have to crop up in a fresh place when the hopes of the surgeon are high, and the fears of the patient are soothed into the belief that he has seen the last of the old plant which has been living upon him so long, must have occurred to everyone who has treated many cases of fungoid skin disease. The severer parasiticides may, it is true, eradicate the mischief, but when the face is attacked such remedies are worse than the disease, and in such cases you may paint, you may rub, you may dose as you will, but the end is-vegetation. There is a plan, however, which is generally successful, and which appears to fulfil the requirements of curing quickly, safely, and pleasantly, which is simply to exclude air, and, it is well to add, light from the surface of the affected spot, when it will be found that the fungus in a short time perishes. The best application is, perhaps, a solution of carbolic acid in Canada balsam. If this be laid on warm with a camel'shair brush, and after being allowed to dry, tinted blacks with a little Indian ink, the fungus will be destroyed, and the patient cured in about a fortnight. I have used a solution of carbolic acid in the proportion of one to ten of Canada balsam, but if necessary the balsam will take up a greater quantity.

Manchester, June 2nd, 1873.

$$
\text { I am, Sir, yours obediently, }
$$
S. Messenger Bradley.

\section{FOREIGN BODY IN THE GLOTTIS.}

\section{To the Editor of THE LANCET.}

Sir,-The following case may be of some interest to your readers, as $I$ am not aware of such a large substance having been known to enter the air-passages.

On the afternoon of Whitmonday last, a man, thirty years of age, who had been "enjoying himself" with some friends at the Crystal Palace, visited a friend's house, where he sat down to a dinner of cold shoulder of mutton. $\mathrm{He}$ had just commenced eating, when he jumped up from his seat at table as if about to vomit; he, however, got only to the door, where he sank down and was soon found to be dead.

No medical assistance was immediately procurable, and no accurate judgment could be formed as to the cause of death.

A coroner's inquest was held upon the body, and adjourned that a post-mortem examination might be made, which I performed with the assistance of $m y$ friend Dr. Stutter.

All the cavities were opened and examined, and found to be healthy. The larynx and trachea were removed, and upon lifting the glottis a foreign body appeared, which, upon being removed, was found to be a piece of meat measuring three inches in length by an inch and a quarter in diameter, and weighing five drachms.

This enormous morsel must have been drawn in by some powerful inspiratory effort whilst in the fauces.

The coroner related a similar case where an inquest had been held upon a lady who was choked from an oyster having been drawn into the larynx; and another case in which a bluebottle fly had occasioned death in the same manner.

I am, Sir, your obedient servant,

F. E. WILKINSON.

Battle Cottage, Sydenham, 14th June, 1870 .

\section{THE DOSE OF THE MURIATE OF BARYTES.}

To the Editor of THE LANCET.

Sir,-Very recently, and by accident, my attention was called to the dose of this medicine as given in the standard works of the day, and I must say it was with much surprise I found it put down as ranging from half a grain to two grains for a dose. And it is further added, at least in some of the works, that in doses of an ounce it would prove poisonous. How such statements got into print it is hard to understand; and, as the medicine is one of great activity, I take leave to draw attention to the point. I have been in the habit of using it for many years, and can state that the proper dose is from the twelfth to the sixteenth of a grain. Very few will bear the eighth. In fact, it is very analogous to the corrosive muriate of mercury, and, if an overdose be given, it will produce precisely the same violent effects. To talk, under these circumstances, of an ounce being poisonous is simply absurd. In a very valuable and nicely arranged chart, just published by Mr. Griffiths, of the Royal College of Surgeons, he very properly calls attention to this point. I may add that originally it was as a saturated solution it was given, and that the dose was four drops, gradually increased to eight, twice in the day. I remain, Sir, yours, \&c.,

Dublin, July 1st, 1873. HenRy Kennedy.

\section{CATGUT SUTURES.}

\section{To the Editor of THE LANCET.}

SIR,-Previous to reading Dr. Ogilvie Will's paper in last week's LANCET, I imagined that carbolised catgut was coming into general use for sutures, and that its advantages were acknowledged by most surgeons.

I have used nothing except catgut for sutures for the last eighteen months in this hospital, and I am satisfied that it is far superior to silk or silver wire. I have not selected cases for its use, as Dr. Will recommends.

Dr. Ogilvie Will removes the catgut suture, and thereby, I think, deprives himself of one of its principal advantages I never remove the sutures, but find that the portion outside the skin drops off after ten days or a fortnight, whilst the remaining portion inside the wound is, I suppose, absorbed, as I never see anything more of it

I have found the following advantages from the use of the catgut suture:-1. Length of time which it remains in a wound without causing irritation, and without causing subsequent marking of skin. 2. Avoidance of operation of removal, a process always painful, and of ten attended by separation of the edges of a wound from the patient flinch ing. 3. Absence of constriction in the portion of tissue included in the suture, which is very favourable to union by first intention.

I am, Sir, yours obediently,

Lincoln County Hospital, July, 1873.

H. D. MALE, House-Surgeon.

\section{HUMAN REMAINS IN IRISH BOGS.}

To the Editor of THE LANCET.

SIR,-Peat bogs being now extensively utilised for fuel in lieu of coal, other instances of human remains may from time to time be discovered. I therefore beg to forward you what seems to me a simple solution of the difficulty about the disappearance of the skeleton in the two interesting cases you lately recorded. 